\title{
Isolated Non-16/18 High-Risk Human Papillomavirus Cervical Infection: Re-Evaluation After One Year
}

\author{
Infeção Cervical Isolada Com HPV de Alto Risco \\ Excluindo os Serotipos 16/18: Reavaliação Após Um Ano
}

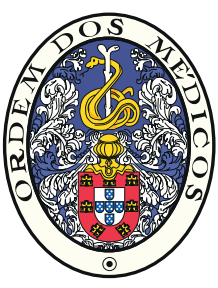

\author{
Sara VARGAS $\rrbracket^{1}$, Maria Pulido VALENTE${ }^{1}$, Margarida Mendes de ALMEIDA², Joaquim NEVES ${ }^{1,3}$, \\ Carlos CALHAZ-JORGE ${ }^{1,3}$ \\ Acta Med Port 2019 Sep;32(9):588-592 - https://doi.org/10.20344/amp.10183
}

\section{ABSTRACT}

Introduction: High-risk human papillomavirus cervical infection is currently a well-established cause of cervical cancer. However, only a few women with persistent infections will develop cervical precancerous and malignant lesions. Approximately $20 \%$ of all cervical cancers are attributable to non-16/18 serotypes. This study aims to evaluate the results of our clinical approach to women with this infection.

Material and Methods: We conducted an observational and prospective study from September 2012 to September 2017, which included women with isolated non-16/18 high-risk human papillomavirus infection (with normal cytology). After re-evaluation, two groups were compared: women with spontaneous regression of the infection and women with persistent infection. Clinical and demographic data were analysed as well as the rate of progression to precancerous and malignant lesions.

Results: We included 165 women, of which 121 were re-evaluated with co-test at least one year later. After re-evaluation, $13.2 \%$ of women revealed precancerous lesions but only two (1.7\%) of them presented high-grade squamous intraepithelial lesions. Sixty-seven women $(55.4 \%)$ showed spontaneous regression of the infection and 54 women (44.6\%) maintained it. Women with persistent infection developed more precancerous lesions $(27.8 \% ; p<0.001)$ and high-grade squamous intraepithelial lesions $(3.7 \% ; p<0.001)$. There was also an association between persistent infection and postmenopausal status.

Discussion: Human papillomavirus $16 / 18$ cervical infection is associated with higher risk of cervical cancer when compared with other serotypes.

Conclusion: Re-evaluation with co-test one year after the diagnosis of isolated non-16/18 human papillomavirus infection seems to be a reasonable approach.

Keywords: Genetic Variation; Papillomaviridae; Papillomavirus Infections; Precancerous Conditions; Uterine Cervical Neoplasms

\section{RESUMO}

Introdução: O cancro cervical é causado pelo papiloma vírus humano de alto risco. No entanto, apenas algumas mulheres com infeções persistentes desenvolvem lesões pré-malignas e malignas. Aproximadamente $20 \%$ destas neoplasias são causadas por serotipos que não os 16 e 18. Este estudo surge com o objetivo de avaliar a nossa prática clínica neste âmbito.

Material e Métodos: Realizámos um estudo observacional e prospetivo entre setembro de 2012 e setembro de 2017, com inclusão de mulheres com infeção cervical isolada com papiloma vírus humano de alto risco, excluindo os serotipos 16 e 18 (com citologia negativa). Após reavaliação, comparámos dois grupos: mulheres que apresentaram resolução espontânea da infeção e mulheres com infeção persistente. Foram analisados dados clínicos e demográficos bem como a taxa de progressão para lesões precursoras e malignas.

Resultados: Incluímos 165 mulheres e reavaliámos com co-teste 121 delas com pelo menos um ano de intervalo. Após reavaliação, $13,2 \%$ desenvolveram lesões precursoras, mas apenas duas $(1,7 \%)$ foram consideradas de alto grau. Sessenta e sete mulheres $(55,4 \%)$ apresentaram resolução espontânea da infeção e $54(44,6 \%)$ mantiveram-na. As mulheres com infeção persistente desenvolveram mais lesões precursoras $(27,8 \% ; p<0,001)$ e de alto grau $(3,7 \% ; p<0,001)$. Constatou-se uma associação entre a persistência da infeção e pós-menopausa.

Discussão: A infecção cervical com serotipos 16/18 associa-se a uma maior risco de desenvolvimento de cancro cervical quando comparada com outros serotipos.

Conclusão: A reavaliação com co-teste um ano após o diagnóstico de infecção cervical isolada com papiloma vírus humano de alto risco, excluindo os serotipos 16 e 18, parece ser uma abordagem adequada.

Palavras-chave: Infecções por Papillomavirus; Lesões Pré-Cancerosas; Neoplasias do Colo do Útero; Papillomaviridae; Variação Genética

\section{INTRODUCTION}

Human papillomavirus (HPV) is the most common sexually transmitted viral infection. Virtually all sexually active people will be infected during their lifetime and some may even be repeatedly infected..$^{1,2}$ More than 100 types of HPV have been identified, but only 15 are considered oncogenic and have cervical tropism. ${ }^{3}$ These are classified as high-risk
HPV (hrHPV) and cause nearly all cases of cervical cancer, the fourth leading cause of female cancer worldwide. . $^{4-6}$ However, not all high-risk types have the same carcinogenic potential, with non-16/18 hrHPV only being responsible for $20 \%$ of all cervical cancers. 5,7

The majority of HPV cervical infections do not cause symptoms or disease, and resolve spontaneously within

1. Departamento de Ginecologia, Obstetrícia e Medicina da Reprodução. Hospital de Santa Maria. Centro Hospitalar de Lisboa Norte. Lisboa. Portugal.

2. Departamento de Anatomia Patológica. Hospital de Santa Maria. Centro Hospitalar de Lisboa Norte. Lisboa. Portugal.

3. Departamento de Ginecologia e Obstetrícia. Faculdade de Medicina. Universidade de Lisboa. Lisboa. Portugal.

$\triangle$ Autor correspondente: Sara Vargas. saravargasp@gmail.com

Recebido: 04 de janeiro de 2018 - Aceite: 10 de abril de 2019 | Copyright @ Ordem dos Médicos 2019 
two years. ${ }^{2,3}$ Persistent infection may lead to precancerous lesions (low and high-grade squamous intraepithelial lesions) and evolve to cancer. Risk factors for HPV persistence are not well defined, but some have been identified: HPV type, viral load, duration of the infection, old age, HIV infection and immune suppression. ${ }^{8}$ Early first sexual intercourse, history of multiple sexual partners, parity and young age at first birth, co-infection with other sexually transmitted agents, tobacco use, and oral contraceptive use for more than five years have also been associated with HPV infection and cervical cancer. ${ }^{5,9}$

Based on the fact that cervical cancer is a preventable disease, there is an attempt to screen all women at risk and to identify and treat precancerous lesions. ${ }^{6,7,10}$ There are currently three types of screening available: cytology, visual inspection with acetic acid and hrHPV testing. Despite being less specific, hrHPV testing is more sensitive, reliable and has a higher negative predictive value. Furthermore, incorporation of hrHPV testing into screening strategies has the potential to increase accuracy and the length of screening intervals. ${ }^{11,12}$ Thus, it was introduced as an adjunct to cytology screening (co-testing) and, in some facilities, as the primary screening test. ${ }^{13-17}$

In Portugal, we have a comprehensive programme for cervical cancer prevention and control, which includes primary, secondary and tertiary prevention. However, it does not cover all the population and leaves room to local organization of opportunistic screening in many health centres and hospitals. According to previous studies, the prevalence of isolated HPV infection in Portuguese women ranges from $15.5 \%$ to $25.4 \%$, and non-16/18 hrHPV are identified in higher proportions than serotypes 16 and $18 .^{18-21}$

At our institution, we introduced opportunistic screening in 2012 with liquid-based cytology and hrHPV testing (co-test), and performed it in women that are followed at our gynaecological and obstetrics department. Most of these women have co-morbidities or high-risk pregnancies. According to the results of the co-test and due to the now accepted risk of progression to high-grade squamous intraepithelial lesions (HSIL) and cancer, women are referred to colposcopy for further evaluation and treatment. Although there are still some doubts about the best approach to women with non-16/18 hrHPV infection with negative cytology, we repeat the co-test one year later, as suggested by recent guidelines. ${ }^{12}$ We also refer women to colposcopy if the infection persists or if a precancerous lesion is identified.

Some studies have evaluated the risk of progression to malignancy or to the persistence of these infections, but all applied heterogenic methodologies. In Portugal, no similar evaluation was performed. This study aims to evaluate the results of our approach to women with isolated non-16/18 hrHPV infection.

\section{MATERIAL AND METHODS}

The Department of Obstetrics and Gynaecology of Hospital de Santa Maria, Centro Hospitalar de Lisboa
Norte, Lisbon, Portugal, is part of a tertiary university/public institution.

We conducted an observational prospective study from September 2012 to September 2017, which included women aged 30 to 65 with diagnosis of isolated non-16/18 hrHPV infection (designation meaning that no other hrHPV was identified and colpocytology evaluation was normal). All women were being followed at our department and the date of diagnosis corresponded to the date of inclusion in our convenience sample. The co-tests performed included liquid-based cytology (ThinPrep® Pap test) and hrHPV testing (Cobas $®$ test, Roche). This test simultaneously provides pooled results on hrHPV (types 31, 33, 35, 39, 45, $51,52,56,58,59,66,68)$ and individual results on HPV 16 and 18. Cytological results were reported according to the Bethesda system.

Based on the result of an isolated non-16/18 hrHPV infection, we informed all women that re-evaluation with co-test should be performed one year later. We contacted every woman who did not attend the follow-up one year after the diagnosis. We also analysed clinical and demographic data including age, age of menarche and menopause, parity, age of sexual debut and number of sexual partners, tobacco, oral contraceptive use (rate of current users) and co-infection with HIV. After re-evaluation with co-test, we formed and compared two groups: women with spontaneous regression of the infection and women with persistent infection. We examined the rate of progression to precancerous and malignant lesions. We performed statistical analysis with t-test and $X^{2}($ IBM $®$ SPSS $®$ Statistics 24 ) and we considered $p$ values lower than 0.05 as statistically significant.

Ethics committee approval was not required because no additional interventions were performed besides those established by institutional guidelines.

\section{RESULTS}

We included 165 women in this study. The demographic and clinical characteristics analysed are represented in Table 1. Twenty-two (13.3\%) women had HIV infection, but most had negative viral load.

Among all women, only 121 women were re-evaluated with co-test: $86.8 \%(n=105)$ after one year, $10.7 \%(n=13)$ after two years, $1.7 \%(n=2)$ after three years and $0.8 \%$ $(n=1)$ after four years. Thirty-four women $(20.6 \%)$ did not return for further evaluation, while others $(6.1 \%)$ will only be re-evaluated in the future.

After re-evaluation, 16 women (13.2\%) revealed precancerous lesions: four (3.3\%) atypical squamous cells of undetermined significance (ASCUS), ten (8.3\%) LSIL and two $(1.7 \%) \mathrm{HSIL}$. Only one of the women who developed LSIL showed spontaneous regression of the infection. HSIL were not confirmed by histological evaluation. We did not identify any malignant lesions.

Sixty-seven women $(55.4 \%)$ had spontaneous resolution of the infection. Fifty women (41.3\%) maintained isolated non-16/18 hrHPV infection, two (1.6\%) got co-infected 
Table 1 - Demographic and clinical characteristics

\begin{tabular}{|c|c|c|c|c|c|}
\hline & Total & Re-evaluated & $\begin{array}{c}\text { Spontaneous resolution } \\
\text { of the infection }\end{array}$ & $\begin{array}{l}\text { Persistent } \\
\text { infection }\end{array}$ & $\boldsymbol{p}^{\mathrm{a}}$ \\
\hline Age & $45(30-65)$ & $46(30-65)$ & $44(30-65)$ & $47(30-65)$ & n.s. ${ }^{c}$ \\
\hline Menarche & $13(9-19)$ & $13(9-19)$ & $13(9-18)$ & $13(10-19)$ & n.s. \\
\hline Post-menopause & $24.9 \%(41 / 165)$ & $30.6 \%(37 / 121)$ & $26.9 \%(18 / 67)$ & $35.2 \%(19 / 54)$ & 0.01 \\
\hline $\begin{array}{l}\text { Parity } \\
\text { Nulliparous } \\
\text { Primiparous } \\
\text { Multiparous }\end{array}$ & $\begin{array}{l}20.3 \%(33 / 163) \\
30.7 \%(50 / 163) \\
49.1 \%(80 / 163)\end{array}$ & $\begin{array}{c}21 \%(25 / 119) \\
31.1 \%(37 / 119) \\
47.9 \%(57 / 119)\end{array}$ & $\begin{array}{l}23.1 \%(15 / 65) \\
29.2 \%(19 / 65) \\
47.7 \%(31 / 65)\end{array}$ & $\begin{array}{l}18.5 \%(10 / 54) \\
33.3 \%(18 / 54) \\
48.2 \%(26 / 54)\end{array}$ & n.s \\
\hline Coitarche & $19(12-41)$ & $19(12-41)$ & $18(13-34)$ & $19(12-41)$ & n.s. \\
\hline Number of sexual partners & $4(1-40)$ & $4(1-40)$ & $3(1-20)$ & $5(1-40)$ & n.s. \\
\hline Oral contraception & $37.8 \%(59 / 156)$ & $34.5 \%(39 / 113)$ & $34.9 \%(22 / 63)$ & $34 \%(17 / 50)$ & n.s. \\
\hline Tobacco use & $30.6 \%(45 / 147)$ & $32.7 \%(34 / 104)$ & $40.4 \%(23 / 57)$ & $23.4 \%(11 / 47)$ & n.s. \\
\hline HIV infection & $13.3 \%(22 / 165)$ & $14,1 \%(17 / 121)$ & $9 \%(6 / 67)$ & $20.4 \%(11 / 54)$ & n.s. \\
\hline $\begin{array}{l}\text { Precancerous lesions } \\
\text { HSIL }\end{array}$ & - & $\begin{array}{c}13.2 \%(16 / 121) \\
1.7 \%(2 / 121)\end{array}$ & $\begin{array}{c}1.5 \%(1 / 67) \\
0 \%(0 / 67)\end{array}$ & $\begin{array}{c}27.8 \%(15 / 54) \\
3.7 \%(2 / 54)\end{array}$ & $\begin{array}{l}<0.001 \\
<0.001\end{array}$ \\
\hline
\end{tabular}

Data expressed as mean (maximum-minimum) or as frequency ( $\mathrm{n} /$ total)

a Comparative analysis of women with spontaneous regression of the infection and women with persistent infection

b Identified by cytology

c Non-significant

(one with serotype 16 and the other with serotype 18) and two $(1.6 \%)$ developed an isolated 16 or 18 infection. None of these four women developed precancerous lesions, but $27.8 \%$ of those infected with non-16/18 hrHPV revealed cytological abnormalities ( $3.7 \% \mathrm{HSIL})$.

There was an association between persistent infection and the development of precancerous lesions $(p<0.001)$ and HSIL $(p<0.001)$. Postmenopausal status was also associated with persistent infection $(p=0.01)$. Besides that, we did not find other statistical differences in the analysed demographic and clinical characteristics between women who showed spontaneous resolution of the infection and those who revealed persistent infection (Table 1).

\section{DISCUSSION}

Persistent hrHPV cervical infection is associated with cervical dysplasia and malignancy, which typically develops within five to ten years. ${ }^{2,4,22,23}$ Furthermore, the risk of progression with persistent non-16/18 hrHPV cervical infection is lower than persistent infection with serotypes $16 / 18$, but it is still higher compared to no infection. ${ }^{24-28}$

In our study, we re-evaluated 121 women $(73.3 \%$ of our sample) who had an isolated non-16/18 hrHPV cervical infection. The majority ( $86.8 \%)$ of them were re-evaluated after one year. The rate of spontaneous regression of the infection (55.4\%) and the rate of development of precancerous lesions $(13.2 \% ; 1.7 \% \mathrm{HSIL})$ were consistent with previous studies. ${ }^{25,29,30}$ Due to the lack of information regarding all the results of previous screenings performed in these women, we do not know the real duration of these infections. Additionally, we do not know how much time passed until the development of a lesion. Nevertheless, this represents a frequent scenario, since not all women are regularly screened and the risk of cancer is real. Furthermore, the group of women with persistent infection developed more precancerous lesions (27.8\%) and HSIL (3.7\%), which is in agreement with previous publications that identified the persistence of infection as the major risk factor in the development of cervical cancer. ${ }^{7-9}$

The average age at re-evaluation was 46 years old and almost $31 \%$ of these women were postmenopausal. In our institution we follow a high number of postmenopausal women and women infected with HIV. Knowing that the risk of persistent hrHPV cervical infection in young women is lower than in older women, ${ }^{28,30}$ our population might require special care and follow-up. In fact, we found an association between postmenopausal status and persistent infection.

Regarding older women, previous studies suggest that the latency of HPV is possible, as it is in women with HIV infection. ${ }^{31-33}$ Besides that, HIV co-infection is also a known risk factor for the development of cervical cancer.

Even though we have performed an analysis of previously identified risk factors for persistence of the infection, we did not find other statistical differences in the analysed demographic and the clinical characteristics between women who had spontaneous resolution of the infection and those with persistent infection.

The relatively short duration of follow-up and small number of cases included in our sample may represent a limitation of this study, but until now no similar studies were performed in Portugal. Our results might not be generalizable to all populations because baseline characteristics might be different. Still, since HPV testing is not available in all health care centres in our country, recognising its value, especially in groups at higher risk of developing cervical lesions, seems to be essential. According to our results, to the demographic and clinical characteristics of our population and even though non-16/18 hrHPV are responsible for a minority of all cases of cervical cancer, our approach and results seem to be acceptable for our reality. However, the 
test used (Cobas ${ }^{\circ}$ Roche) does not differentiate between individual non-16/18 HPV types and we know that their isolated potential of malignancy is different. One of the strengths of our study is that we only included women aged 30 to 65 , as it is recommended. ${ }^{12,34}$

These preliminary results also support the opinion that referring all women with isolated non-16/18 hrHPV infection to colposcopy might not be the best option. ${ }^{12}$ Nevertheless, additional studies are needed to evaluate individual risks of progression to precancerous and malignant lesions. Finally, these women may be reassured that the infection might resolve spontaneously, after making sure that they understand the importance of re-evaluation.

\section{CONCLUSION}

According to our results, re-evaluation with co-test one year after the diagnosis of isolated non-16/18 hrHPV cervical infection seems to be a reasonable approach in our reality, since $55.4 \%$ of these women showed spontaneous regression of this infection and only $1.7 \%$ developed HSIL, that were not confirmed in a biopsy specimen.

\section{PROTECTION OF HUMANS AND ANIMALS}

The authors declare that the procedures were followed according to the regulations established by the Clinical

\section{REFERENCES}

1. Bosch FX, Manos MM, Muñoz N, Sherman M, Jansen AM, Peto J, et al. Prevalence of human papillomavirus in cervical cancer: a worldwide perspective. International biological study on cervical cancer (IBSCC) Study Group. J Natl Cancer Inst. 1995;87:796-802.

2. Bosch FX, Burchell AN, Schiffman M, Giuliano AR, de Sanjose S, Bruni $\mathrm{L}$, et al. Epidemiology and natural history of human papillomavirus infections and type-specific implications in cervical neoplasia. Vaccine. 2008;26:K1-16.

3. Schiffman M, Castle PE, Jeronimo J, Rodriguez AC, Wacholder S Human papillomavirus and cervical cancer. Lancet. 2007;370:890-907.

4. De Sanjose S, Quint WG, Alemany L, Geraets DT, Klaustermeier JE, Lloveras $\mathrm{B}$, et al. Human papillomavirus genotype attribution in invasive cervical cancer: a retrospective cross-sectional worldwide study. Lancet Oncol. 2010;11:1048-5.

5. Bruni L, Albero G, Serrano B, Mena M, Gómez D, Muñoz J, et al. ICO Information Centre on HPV and Cancer (HPV Information Centre). Human Papillomavirus and Related Diseases in the World. Summary Report 27 July 2017. Barcelona: HPV Information Centre; 2017.

6. World Health Organization. Guidelines Approved by the Guidelines Review Committee. Comprehensive Cervical Cancer Control: A Guide to Essential Practice. $2^{\text {nd }}$ ed. Geneva: WHO; 2014.

7. Clifford G, Franceschi S, Diaz M, Muñoz N, Villa LL. HPV typedistribution in women with and without cervical neoplastic diseases. Vaccine. 2006;24:S3/26-34.

8. Plummer M, Schiffman M, Castle PE, Maucort-Boulch D, Wheeler CM. A 2-year prospective study of human papillomavirus persistence among women with a cytological diagnosis of atypical squamous cells of undetermined significance or low-grade squamous intraepithelial lesion. J Infect Dis. 2007;195:1582-9.

9. Luhn P, Walker J, Schiffman M, Zuna RE, Dunn ST, Gold MA, et al. The role of co-factors in the progression from human papillomavirus infection to cervical cancer. Gynecol Oncol. 2013;128:265-70.

10. Pimple S, Mishra G, Shastri S. Global strategies for cervical cancer prevention. Curr Opin Obstet Gynecol. 2016;28:4-10.

11. Rao A, Sandri MT, Sideri M, Young S, Sharma A, Behrens C. Comparison of hybrid capture 2 high-risk HPV results in the low positive range with cobas ${ }^{\circledR}$ HPV test results from the ATHENA Study. J Clin Virol. 2013;58:161-7.

12. Saslow D, Solomon D, Lawson HW, Killackey M, Kulasingam SL, Cain J, et al. American Cancer Society, American Society for Colposcopy
Research and Ethics Committee and to the Helsinki Declaration of the World Medical Association.

\section{DATA CONFIDENTIALITY}

We declare having followed the protocols in use in our working centre regarding patients' data publication.

\section{CONFLICTS OF INTEREST}

Joaquim Neves participates as trainer and lecturer in clinical meetings for Amgen, Atral-Cipan, Azevedos, Bayer, Bial, Effik, Gedeon Richter, GSK, Hikma, Laboratórios Vitória, Lilly, MSD, Novartis, OM Pharma, Pfizer, Roche Farmacêutica, Sanofi, Sanofi Pasteur MSD, Servier, Tecnifar, Tecnimed, Wise, Zambon.

All other co-authors have no conflicts to declare, related to the topic of the paper.

\section{FUNDING SOURCES}

This research received no specific grant from any funding agency in the public, commercial, or not-for-profit sectors. and Cervical Pathology, and American Society for Clinical Pathology screening guidelines for the prevention and early detection of cervical cancer. CA Cancer J Clin. 2012;62:147-72.

13. Cuzick J, Bergeron C, von Knebel Doeberitz M, Gravitt P, Jeronimo J, Lorincz AT, et al. New technologies and procedures for cervical cancer screening. Vaccine. 2012;30:F107-16.

14. Castle PE, de Sanjosé S, Qiao YL, Belinson JL, Lazcano-Ponce E, Kinney W. Introduction of human papillomavirus DNA screening in the world: 15 years of experience. Vaccine. 2012;30:F117-22.

15. Koliopoulos G, Nyaga VN, Santesso N, Bryant A, Martin-Hirsch PP, Mustafa RA, et al. Cytology versus HPV testing for cervical cancer screening in the general population. Cochrane Database Syst Rev. 2017;8:CD008587.

16. Kitchener HC, Gilham C, Sargent A, Bailey A, Albrow R, Roberts C, et al. A comparison of HPV DNA testing and liquid based cytology over three rounds of primary cervical screening: extended follow up in the ARTISTIC trial. Eur J Cancer. 2011;47:864-71.

17. Wright TC Jr, Massad LS, Dunton CJ, Spitzer M, Wilkinson EJ, Solomon D; 2006 American Society for Colposcopy and Cervical Pathology-sponsored Consensus Conference. 2006 consensus guidelines for the management of women with abnormal cervical cancer screening tests. Am J Obstet Gynecol. 2007;197:346-55.

18. Pista A, Oliveira A, Verdasca N, Ribeiro F. Single and multiple human papillomavirus infections in cervical abnormalities in Portuguese women. Clin Microbiol Infect. 2011;17:941-6.

19. Nobre RJ, Cruz E, Real O, de Almeida LP, Martins TC. Characterization of common and rare human papillomaviruses in Portuguese women by the polymerase chain reaction, restriction fragment length polymorphism and sequencing. J Med Virol. 2010;82:1024-32.

20. Pista A, de Oliveira CF, Cunha MJ, Paixao MT, Real O. Prevalence of human papillomavirus infection in women in Portugal: the CLEOPATRE Portugal study. Int J Gynecol Cancer. 2011;21:1150-8.

21. Vieira L, Almeida A. The cytology and DNA detection by the PapilloCheck(®) test in the diagnosis of human papillomavirus infection. Eur J Microbiol Immunol. 2013;3:61-7.

22. Bosch FX, Lorincz A, Muñoz N, Meijer CJ, Shah KV. The causal relation between human papillomavirus and cervical cancer. J Clin Pathol. 2002;55:244-65

23. Rositch AF, Koshiol J, Hudgens MG, Razzaghi H, Backes DM, Pimenta JM, et al. Patterns of persistent genital human papillomavirus 
infection among women worldwide: a literature review and metaanalysis. Int J Cancer. 2013;133:1271-85.

24. Khan MJ, Castle PE, Lorincz AT, Wacholder S, Sherman M, Scott DR, et al. The elevated 10 -year risk of cervical precancer and cancer in women with human papillomavirus (HPV) type 16 or 18 and the possible utility of type-specific HPV testing in clinical practice. J Natl Cancer Inst. 2005;97:1072-9.

25. Castle PE, Wacholder S, Sherman ME, Lorincz AT, Glass AG, Scott DR, et al. Absolute risk of a subsequent abnormal pap among oncogenic human papillomavirus DNA-positive, cytologically negative women. Cancer. 2002;95:2145-51.

26. Kjær SK, Frederiksen K, Munk C, Iftner T. Long-term absolute risk of cervical intraepithelial neoplasia grade 3 or worse following human papillomavirus infection: role of persistence. J Natl Cancer Inst. 2010;102:1478-88.

27. Serra H, Pista A, Figueiredo P, Urbano A, Avilez F, De Oliveira CF. Cervix uteri lesions and human papiloma virus infection (HPV): detection and characterization of DNA/HPV using PCR. Acta Med Port. 2000;13:181-92.

28. Rodríguez AC, Schiffman M, Herrero R, Wacholder S, Hildesheim A, Castle PE, et al. Rapid clearance of human papillomavirus and implications for clinical focus on persistent infections. J Natl Cancer Inst. 2008;100:513-7.
29. Katki HA, Schiffman M, Castle PE, Fetterman B, Poitras NE, Lorey T, et al. Five-year risks of $\mathrm{CIN} 3+$ and cervical cancer among women who test Pap-negative but are HPV-positive. J Low Genit Tract Dis. 2013;17:S56-63.

30. Ho GY, Bierman R, Beardsley L, Chang CJ, Burk RD. Natural history of cervicovaginal papillomavirus infection in young women. $\mathrm{N}$ Engl J Med. 1998;338:423-8.

31. Strickler HD, Burk RD, Fazzari M, Anastos K, Minkoff H, Massad LS, et al. Natural history and possible reactivation of human papillomavirus in human immunodeficiency virus-positive women. J Natl Cancer Inst. 2005;97:577-86.

32. Brown DR, Weaver B. Human papillomavirus in older women: new infection or reactivation? J Infect Dis. 2013;207:211-2.

33. Rositch AF, Burke AE, Viscidi RP, Silver MI, Chang K, Gravitt PE. Contributions of recent and past sexual partnerships on incident human papillomavirus detection: acquisition and reactivation in older women. Cancer Res. 2012;72:6183.

34. Moutinho JA, Vitorino A, Pacheco A, Pedro A, Matos A, Moniz AP, et al. Consenso sobre infecção por HPV e neoplasia intraepitelial do colo vulva e vagina. Sociedade Portuguesa de Ginecologia — Secção Portuguesa de Colposcopia e Patologia Cervico-vulvovaginal. Coimbra: SPC; 2014 